\title{
PENINGKATAN PENGETAHUAN PENJAMAH MAKANAN TERKAIT PEMBINAAN KANTIN SEHAT
}

\author{
Putri Ronitawati $^{1^{*}}$, Rachmanida Nuzrina ${ }^{2}$, Prita Dhyani Swamilaksita ${ }^{3}$, \\ Laras Sitoayu $^{4}$, Vitria Melani ${ }^{5}$, Nazhif Gifari ${ }^{6}$ \\ 1,2,3,4,5,6 Program Studi Gizi, Fakultas Ilmu-ilmu Kesehatan, Universitas Esa Unggul, Indonesia \\ ${ }^{1}$ putri.ronitawati@esaunggul.ac.id, ${ }^{2}$ rachmanida.nuzrina@esaunggul.ac.id, \\ ${ }^{3}$ prita.dhyani@esaunggul.ac.id, ${ }^{4}$ laras@esaunggul.ac.id, ${ }^{5}$ vitria@esaunggul.ac.id, \\ ${ }^{6}$ nazhif.gifari@esaunggul.ac.id
}

\begin{abstract}
ABSTRAK
Abstrak: Universitas Esa Unggul merupakan institusi pendidikan yang memiliki fasilitas kantin yang berada dalam lingkungan kampus. Saat ini, kantin Esa Unggul dikelola oleh PT. Indonusa dan Departemen sarana prasarana Universitas Esa Unggul (UEU) belum mendapat pembinaan yang terkait tentang higiene sanitasi. Pembinaan ini membutuhkan kerjasama semua pihak baik dari Dinas Kesehatan maupun Institusi terkait dalam lingkungan Universitas Esa Unggul (UEU). Kantin UEU memiliki 12 gerai yang terdiri dari 26 penjamah makanan. Kantin memiliki peranan untuk memenuhi kebutuhan mahasiswa dan pegawai Universitas Esa Unggul. Tindakan preventif dilakukan dalam upaya untuk mencegah keracunan dan bahaya lain yang terkait dengan food borne disease. Kegiatan yang telah dilakukan berupa observasi awal terkait standar sebuah kantin sehat serta edukasi mengenai kantin yang sehat, higiene sanitasi, higiene personal, menu yang sesuai dengan prinsip gizi seimbang serta perubahan setelah dilakukan kegiatan tersebut. Hasilnya menunjukkan bahwa ada perubahan yang baik terkait pengetahuan penjamah makanan serta adanya perubahan perilaku yang tercermin dengan penggunaan Alat Pelindung Diri (APD) yang lengkap.
\end{abstract}

Kata Kunci: Higiene personal; Higiene sanitasi, Kantin sehat.

Abstract: Universitas Esa Unggul is an educational institution that has canteen facilities within the campus environment. At present, the canteen managed by Pt. Indonesia and the Department of Infrastructure has not received relevant guidance on sanitization hygiene. This guidance requires cooperation off all parties, both from the Health Service and related institutions within Universitas Esa Unggul. UEU Canteen has 12 outlets consisting of 26 food handlers. The canteen has a role to meet the needs of students and employees of Universitas Esa Unggul. Preventive action is taken in an effort to prevent poisoning and other hazards associated with foodborne disease. Activities have carried out in the form of preliminary observations related to the standards of a healthy canteen as well as education about healthy canteens, hygiene sanitation, personal hygiene, menus that are in accordance with the principles of balanced nutrition and changes after the activities are carried out. The results show that there are good changes related to knowledge of food handlers as well as changes in behavior reflected by the use of personal protective equipment or PPE that is complete.

Keywords : Healthy canteen; Personal hygiene, Hygiene sanitation.

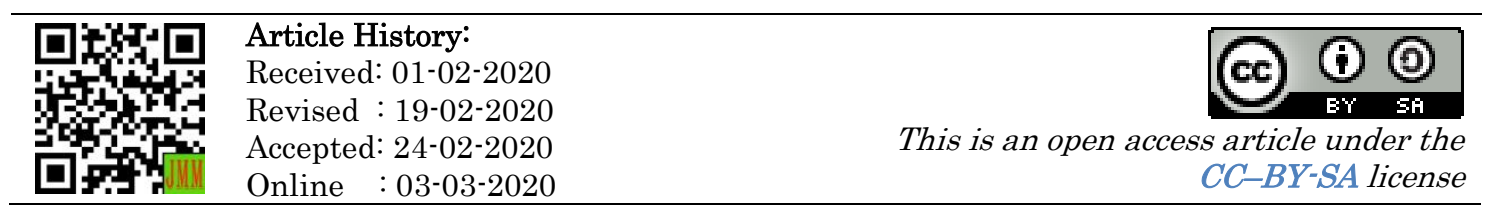




\section{A. LATAR BELAKANG}

Studi literatur yang dilakukan oleh Arisanti (2018) menunjukkan bahwa dalam kurun waktu 5 tahun (2000-2015) terjadi 1.176 KLB keracunan pangan. Kejadian tertinggi terjadi di Jawa Tengah dan Jawa Barat sebanyak 163 kejadian. Laporan kasus menunjukkan 61.119 kasus keracunan pangan dan 291 kematian. WHO juga memperkirakan 31 agen berbahaya penyebab 600 juta kesakitan dan 420.000 kematian. Agen penyebab diare seperti Norovirus, Salmonella enterica, Camplycobacter dan Escherichia coli. Berdasarkan data PHEOC (2017) terdapat 163 wabah penyakit bawaan makanan di seluruh Indonesia. Saat ini, KLB keracunan makanan menempati urutan kedua setelah KLB dan Difteri. Kejadian tersebut bersumber dari pangan siap saji, $36 \%$ masakan rumah tangga.

Salah satu kebutuhan pokok manusia adalah pangan. Pangan yang dikonsumsi harus bermutu serta memenuhi kriteria keamanan pangan. Kantin universitas merupakan tempat yang mempunyai peranan penting untuk memenuhi kebutuhan makanan jajanan. Makanan jajanan yang dijual di kantin umumnya memiliki variasi yang sangat beragam, dengan harga yang relatif murah, serta mudah dijangkau oleh mahasiswa. Pemenuhan kebutuhan terkait makanan jajanan yang higienis dipengaruhi oleh faktor sanitasi tempat dan higiene pedagang makanan perlu untuk dilakukan. Penjamah makanan secara langsung berhubungan dengan makanan dan peralatan mulai dari tahap persiapan, pembersihan, pengolahan, pengangkutan sampai penyajian adalah pedagang makanan (Anonymous, 2003a), (Ramli, 2018).

Sanitasi makanan merupakan usaha pencegahan yang mengutamakan kegiatan dan tindakan untuk menghindari segala cemaran baik fisik, kimia dan biologis yang dapat mengganggu kesehatan, mulai dari bahan baku, persiapan sampai sebelum makanan dan minuman diproduksi. Selama proses pengolahan, penyimpanan, pengangkutan sampai pada saat dimana makanan dan minuman tersebut siap untuk dikonsumsi konsumen (Anonymous, 2011), (Jiastuti, 2018), (Efendi, Andriyani, \& Mustakim, 2018).

Kantin merupakan tempat mengolah makanan yang kemudian dihidangkan kepada konsumen. Hal ini menyebabkan kantin beresiko menjadi tempat penyebaran segala penyakit dengan media makanan dan minuman yang berpotensi menyebabkan penyakit bawaan makanan bila tidak dikelola dan ditangani dengan baik (Anonymous, 2003b), (Sunarya \& Yudhastuti, 2019). Kualitas menu kantin yang baik akan memengaruhi puas atau tidaknya konsumen. Dengan kondisi tersebut maka perhatian para pelaku bisnis dan pengelola kantin perguruan tinggi penting untuk selalu meningkatkan aspek keamanan pangan sehingga lebih memenuhi tuntutan konsumen dan meningkatkan kinerja kantin (Sucipto, Rahman, \& Mustaniroh, 2018). 
Permasalahan yang sering timbul pada penyediaan makanan di kantin karena tidak sesuai dengan syarat sanitasi meliputi faktor bangunan, konstruksi, dan fasilitas sanitasi (Anonymous, 2003b). Selain itu terkait higiene personal penjamah makanan maka setiap karyawan yang menangani makanan harus memenuhi beberapa persyaratan di antaranya memiliki sertifikat kursus higiene sanitasi makanan dan buku pemeriksaan kesehatan yang berlaku, sehat jasmani yang dibuktikan dengan surat keterangan dokter, tidak mengidap penyakit menular seperti tipus, kolera, TBC, hepatitis dan lain - lain atau pembawa kuman (carrier) (Anonymous, 2011), (Rohmah, Cholifah, \& Rezania, 2019). Seluruh proses pengolahan makanan harus dilakukan dengan cara terlindung dari kontak langsung dengan tubuh. Perlindungan kontak langsung dengan makanan dapat dilakukan menggunakan beberapa cara, yaitu memakai celemek dan tidak menyisir rambut di dekat makanan yang sudah dikelola (Anonymous, 2011), (Sunarya \& Yudhastuti, 2019), (Khaerunisa, Cahyono, \& Binawan, 2019). Kasus keracunan bisa diakibatkan oleh faktor kebersihan dari makanan dan food handler. Perilaku cuci tangan merupakan salah satu cara untuk mencegah penyakit infeksi (Purwanti, T, \& A, 2015). Selama ini kantin masih kurang memperhatikan keamanan pangan baik dari jenis makanan yang di jual maupun wadah kemasan tanpa memperhatikan bahaya dan nilai gizi (Mukhodim, Hanum, \& Latifah, 2019).

Universitas Esa Unggul merupakan institusi pendidikan yang memiliki fasilitas kantin yang berada dalam lingkungan kampus. Penelitian sebelumnya menunjukkan bahwa penjamah belum pernah mengikuti pelatihan, lingkungan kantin yang kurang baik, dan penerapan higiene sanitasi yang kurang baik (Swamilaksita \& Pakpahan, 2016) (Fithri, 2016). Saat ini, kantin Esa Unggul dikelola oleh PT. Indonusa dan Departemen sarana prasarana Universitas Esa Unggul (UEU) belum mendapat pembinaan yang terkait tentang higiene sanitasi. Kantin UEU memiliki 12 gerai yang terdiri dari 26 penjamah makanan. Kantin memiliki peranan untuk memenuhi kebutuhan mahasiswa dan pegawai Universitas Esa Unggul. Penelitian Yulia (2016), menunjukkan ada hubungan antara pelaksanaan enam prinsip higiene sanitasi makanan minuman dan sarana sanitasi dengan angka kuman pada peralatan makan dan minum di sekitar kantin. Ada hubungan antara pengetahuan, pendidikan dan lingkungan dengan kualitas sarana sanitasi kantin (Chusna, 2014), (Rohmah et al., 2019). Adanya perbedaan pengetahuan dan sikap sebelum dan sesudah penyuluhan menunjukkan bahwa pengetahuan yang baik dari pengelola kantin memiliki kecenderungan meningkatkan kelaikan kantin sehat sebesar 22,080 kali lebih besar dibandingkan dengan pengetahuan pengelola kantin yang kurang (Rismawati, 2018), (Khairina, A.D., Palupi, I.R., \& Prawiningdyah, 2019).

Atas dasar inilah, perlu adanya tindakan preventif dan promotif yang dilakukan dalam upaya untuk mencegah keracunan dan bahaya lain yang 
terkait dengan food borne disease sehingga pembinaan kantin sehat di UEU dapat dilaksanakan dengan baik.

\section{B. METODE PELAKSANAAN}

Kegiatan pengabdian masyarakat dilaksanakan selama 2 minggu di bulan Oktober 2019 di kantin Universitas Esa Unggul. Khalayak Sasaran adalah semua penjamah makanan di kantin Universitas Esa Unggul. Program ini diawali dengan memberitahukan kepada pihak Universitas Esa Unggul tentang perizinan untuk melakukan pembinaan pada penjual makanan di kantin Universitas Esa Unggul. Semua penjamah makanan di kantin Universitas Esa Unggul wajib berpartisipasi dalam kegiatan ini. Kantin Esa Unggul memiliki 12 gerai dan 26 penjamah makanan. Pada awal kegiatan ini akan dilakukan observasi kelayakan higiene sanitasi kemudian dilanjutkan dengan pengambilan data mengenai pengetahuan dan sikap penjamah makanan terhadap praktik keamanan pangan makanan jajanan serta observasi awal sebelum dilakukan pembinaan. Hal ini dilakukan untuk melihat bagaimana pengetahuan dan sikap para penjamah makanan. Intervensi yang diberikan akan dilakukan beberapa kali berupa pemberian penyuluhan edukasi, pemberian materi tentang bagaimana kantin sehat, apa saja yang harus diperhatikan pada pengolahan makanan, batas penggunaan bahan tambahan pangan yang dianjurkan. Pada kegiatan ini akan dilakukan pre-test dan post-test untuk melihat pengaruh dari pemberian edukasi pengetahuan tersebut.

Dalam pelaksanaan kegiatan ini, kami bekerjasama dengan pihak pengelola kantin Universitas Esa Unggul dengan harapan pembinaan kantin sehat dapat terlaksana dengan baik. Selain itu, apabila hasil baseline data dan observasi mengenai kantin Universitas Unggul menunjukkan bahwa perlu adanya perbaikan sarana prasarana maka kami mengharapkan dapat ditindaklanjuti oleh pihak pengelola. Dalam pembinaan kantin terkait dengan fasilitas keselamatan kerja, membutuhkan kerjasama dengan Program Studi Kesehatan Masyarakat.

\section{HASIL DAN PEMBAHASAN}

Kegiatan pembinaan kantin sehat beriringan dengan adanya lomba kantin sehat. Selain dosen Program Studi Gizi, Universitas Esa Unggul bekerjasama dengan Sudinkes Jakarta Barat dan Puskesmas Duri Kepa Jakarta Barat. Dalam membina kantin sehat tentunya, perlu melibatkan banyak pihak seperti Sarana Prasarana, PT. Indonusa serta seluruh civitas akademika. Sebelum melakukan pembinaan, kegiatan ini disosialisasikan dengan mengundang perwakilan dari masing-masing kantin, sarana prasarana, PT Indonusa, Kemahasiswaan dan perwakilan dari Program Studi Gizi dan perwakilan dari Program Studi Kesehatan Masyarakat. 
Kami juga melakukan observasi pada kantin esa unggul terkait kelayakan hygiene sanitasi dari kantin tersebut.

Kantin yang sehat dapat tercipta dengan adanya kerja sama dari berbagai pihak bukan hanya tim abdimas, namun juga berbagai biro di lingkungan Universitas Esa Unggul, Civitas Akademika dan juga mahasiswa. Selain itu pihak Kampus juga mengundang Suku Dinas Kesehatan dan Puskesmas Duri Kepa untuk membantu membina Kantin Sehat. Rapat persiapan dan koordinasi membentuk satu kesepakatan untuk membina dan mengubah kantin Universitas Esa Unggul menjadi Kantin Sehat dan diikutsertakan dalam lomba antar perguruan tinggi. Rapat tersebut menghasilkan noktah kesepakatan yang ditandatangani oleh semua peserta yang hadir dalam rapat tersebut termasuk perwakilan masing-masing kantin, perwakilan Sudinkes Jakarta Barat, perwakilan Puskesmas Kecamatan Kebon Jeruk dan perwakilan Puskesmas Duri Kepa serta Biro-biro, PT dan Program Studi yang terlibat. Selain itu, perwakilan dari Puskesmas Duri Kepa melakukan edukasi mengenai Keamanan Pangan yang disampaikan oleh Pak Khaerul.

Pembinaan kantin sehat tidak hanya dilakukan pada penjamah makanannya saja namun kelaikan fasilitas serta Kesehatan Keselamatan Kerja (K3) juga menjadi bagian yang penting. Tim abdimas melakukan kerja sama dengan dengan pihak terkait, seperti renovasi bangunan kantin, penyediaan alat pemadam kebakaran, denah rute evakuasi serta penambahan wastafel dan toilet, pembuatan pintu disetiap kantin sampai pembuatan papan nama masing-masing kantin. Adapun hasil sebelum dan sesudah pembinaan sesuai kondisi pada Gambar 1 dan Gambar 2 berikut.

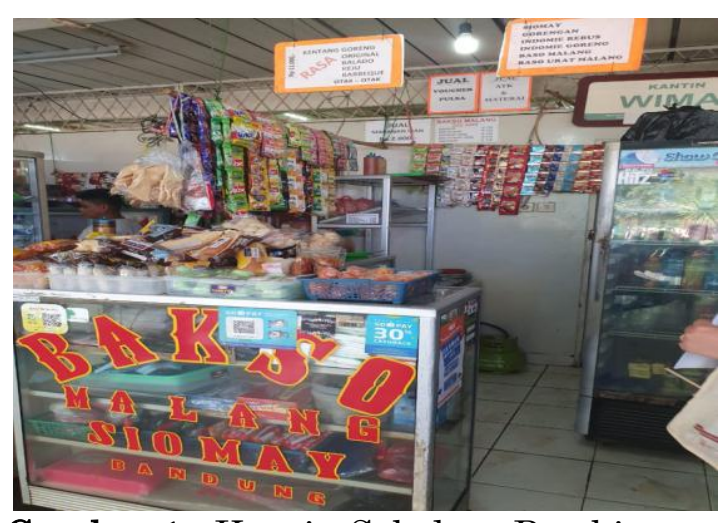

Gambar 1. Kantin Sebelum Pembinaan

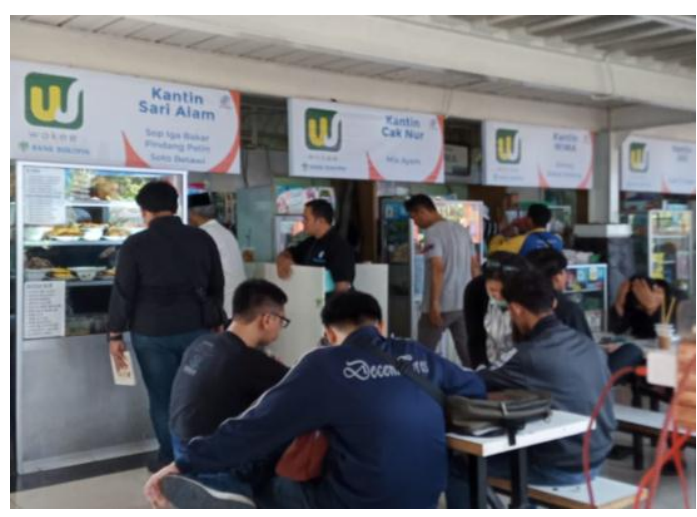

Gambar 2. Kantin Setelah Pembinaan

Edukasi dilakukan selama 7 hari, diawali dengan pre-test di hari pertama dan diakhir kegiatan edukasi diberikan post-test. Tujuannya untuk melakukan evaluasi terhadap materi yang disampaikan selama edukasi. Peserta yang hadir, tim abdimas mewajibkan minimal 1 orang dari masing-masing gerai kantin. Sehingga diharapkan seluruh gerai kantin mau bersama-sama melakukan perubahan sehingga tercipta kantin yang sehat. Hasil pre-test menunjukkan pengetahuan terkait kantin sehat, 
higiene sanitasi dan higiene personal dalam kategori kurang baik dan sikapnya masih negatif serta praktek higiene sanitasi dan higiene personal masih kurang. Standar sebagai kantin sehat juga masih harus diperbaiki dan dilengkapi sarana maupun prasarananya. Proses kegiatan pembinaan didahului dengan melakukan pre-test kepada mitra, proses ini terlihat pada Gambar 3 berikut.

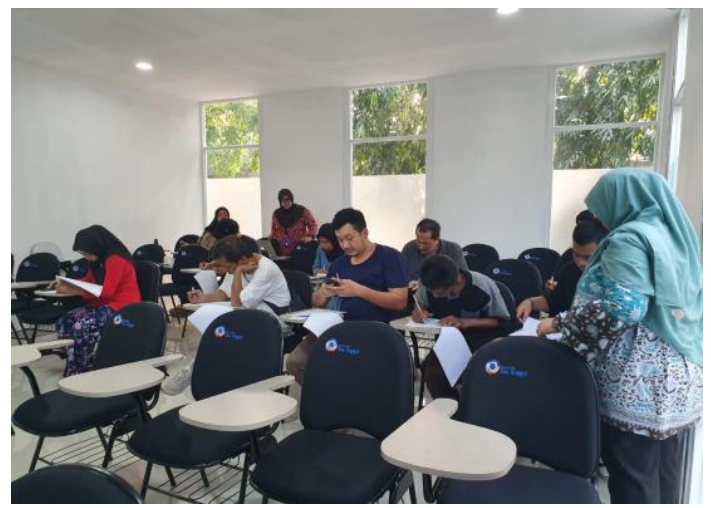

Gambar 3. Kegiatan Pre-Test Sebelum Pembinaan

Edukasi mengenai persyaratan kantin sehat disampaikan oleh Ibu Putri Ronitawati, SKM., M.Si. sesuai Kepmenkes nomor 1098/Menkes/SK/VII/2003 mengenai kelaikan lokasi, bangunan dan fasilitas; pencahayaan; penghawaan terkait sirkulasi udara; pembuangan sampah; ruang pengolahan makanan; penjamah makanan; peralatan makan dan masak, management building, air bersih serta makanan bebas dari cemaran kimia, fisik dan biologi dan kawasan yang bebas rokok. Salah satu syarat kantin sehat adalah harus bebas rokok serta tidak memperjualbelikan rokok. Hal ini sesuai dengan Peraturan Pemerintah pasal 50 ayat 1 dan 2, dalam Peraturan Pemerintah Republik Indonesia Nomor 109 Tahun 2012 tentang Pengamanan Bahan yang Mengandung Zat Adiktif berupa Produk Tembakau Bagi Kesehatan. Universitas Esa Unggul mencanangkan menjadi institusi pendidikan yang bebas rokok termasuk kantin harus bebas dari cemaran asap rokok, sehingga tidak ada lagi orang yang merokok di Kantin dan tidak ada lagi penjual rokok di Kantin.

Penjamah makanan harus memenuhi syarat sesuai Peraturan Menteri Kesehatan RI No. 1096 / MENKES / PER / VI / 2011. Setiap karyawan kantin harus memenuhi syarat tersebut di antaranya memiliki sertifikat kursus higiene sanitasi makanan dan buku pemeriksaan kesehatan yang berlaku, sehat jasmani yang dibuktikan dengan surat keterangan dokter, tidak mengidap penyakit menular seperti tipus, kolera, TBC, hepatitis dan lain - lain atau pembawa kuman (carrier) (Anonymous, 2011). Seluruh proses pengolahan makanan harus dilakukan dengan cara terlindung dari kontak langsung dengan tubuh. Perlindungan kontak langsung dengan makanan dapat dilakukan menggunakan beberapa cara, yaitu memakai celemek pada pakaian dan tidak menyisir rambut di dekat makanan yang 
sudah dikelola (Anonymous, 2011). Proses penyampaian materi tentang tata kelola kantin yang sehat terlihat pada Gambar 4 berikut.

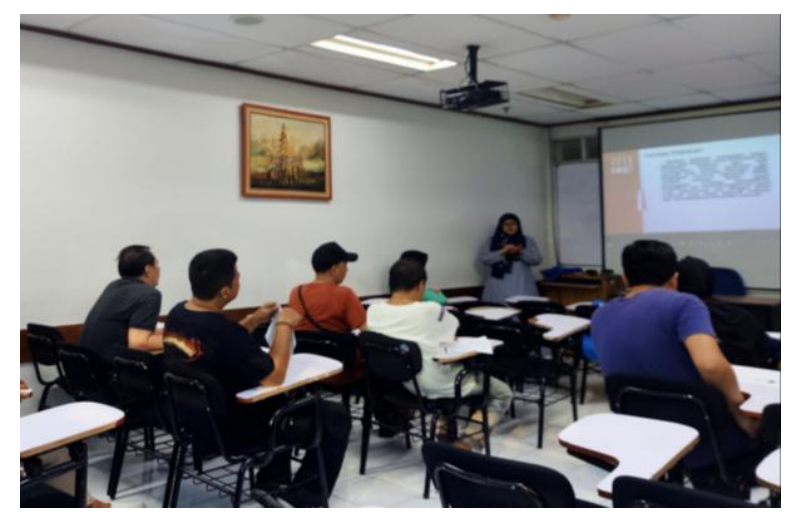

Gambar 4. Edukasi Kantin Sehat

Selain edukasi terkait bagaimana menciptakan kantin yang sehat, perlu menciptakan makanan yang sesuai dengan Prinsip Gizi Seimbang (PGS) yang disampaikan oleh Ibu. Rachmanida Nuzrina, S.Gz., M.Gizi. Hal ini dilakukan terkait pentingnya sosialisasi mengenai gizi seimbang. Apalagi menu yang diperjualbelikan di kantin Esa Unggul hampir sebagian besar merupakan hidangan utama. Ibu Prita Dhyani S, SP., M.Si. memberikan media edukasi dalam bentuk celemek yang merupakan alat pelindung diri yang harus digunakan oleh seorang penjamah makanan. Sosialisasi mengenai Standar Minimum Kantin Kampus. Beberapa peraturan yang diatur di dalamnya adalah kebersihan peralatan, penggunaaan alat pelindung diri (APD) saat memasak, dan kondisi kesehatan penjamah makanan. APD yang wajib digunakan penjamah makanan yaitu celemek, tutup kepala, dan alat bantu mengambil makanan (sarung tangan atau penjepit makanan). Selain itu, penjamah makanan juga disarankan menggunakan masker.

Diharapkan dengan adanya edukasi yang terintegrasi tidak hanya dapat meningkatkan pengetahuan para penjamah makanan, namun juga merubah sikap dan perilaku para penjamah makanan serta menciptakan kantin yang sehat. Pembinaan Kantin Sehat kami lakukan secara berkesinambungan melalui observasi dan pengontrolan dilakukan seminggu 2 kali serta edukasi pada penjamah makanan dari dosen di Program Studi Gizi dan 2 kali dari Sudinkes Jakarta Barat dan Puskesmas Duri Kepa Jakarta Barat. Kantin Esa Unggul sudah mulai mengalami perubahan setelah pembinaan ini berjalan.

\section{SIMPULAN DAN SARAN}

Setelah dilakukan edukasi, setiap gerai dibantu oleh PT. Indonusa dan Biro Sarana Prasarana mulai berbenah yang ditunjukkan dengan penerangan, lantai yang licin diberikan tatakan kemudian penjamah makanan satu persatu yang berada dimasing-masing gerai kantin mulai 
mengenakan APD lengkap dan pada saat post-test dapat menjawab pertanyaan dan lebih memahami mengenai higiene sanitasi, higiene personal dan keamanan makanan. Hal ini dibuktikan dari hasi post-test, jawaban yang salah lebih sedikit dibandingkan saat pre-test, bahkan banyak juga yang mampu menjawab sebesar $90.2 \%$.

\section{UCAPAN TERIMA KASIH}

Ucapan terimakasih disampaikan kepada seluruh gerai di kantin Esa Unggul yang telah berperan serta dalam kegiatan Pengabdian Masyarakat ini. Selain itu, kami sampaikan ucapan terima kasih kepada PT. Indonusa dan Bagian Sarana Prasarana Universitas Esa Unggul serta Dinas Kesehatan Jakarta Barat dan Puskesmas Duri Kepa atas bantuannya telah bekerjasama dengan baik dalam kegiatan tersebut.

\section{DAFTAR RUJUKAN}

Anonymous. (2003). Pedoman Persyaratan Hygiene Sanitasi Makanan Jajanan Keputusan Menteri Kesehatan Republik Indonesia Nomor 942/MENKES/SK/VII/2003.

Anonymous. (2003). Persyaratan Hygiene Sanitasi Rumah Makan Dan Restoran Keputusan Menteri Kesehatan Republik Indonesia Nomor 1098/MENKES/SK/VII/2003.

Anonymous. (2011). Higiene Sanitasi Jasaboga Peraturan Menteri Kesehatan Republik Indonesia Nomor 1096/MENKES/PER/VI/2011.

Arisanti, R. R., Indriani, C., \& Wilopo, S. A. (2018). Kontribusi agen dan faktor penyebab kejadian luar biasa keracunan pangan di Indonesia: kajian $\begin{array}{llll}\text { sistematis. Berita Kedokteran } & \text { Masyarakat, }\end{array}$ https://doi.org/10.22146/bkm.33852

Chusna, F. (2014). Unnes Journal of Public Health Info Artikel Faktor Yang Mempengaruhi Kualitas Sarana Sanitasi Kantin. 3(3), 1-10.

Efendi, R., Andriyani, A., \& Mustakim, M. (2018). Analisis Faktor-Faktor Yang Berhubungan Dengan Higiene Dan Sanitasi Di Kantin Universitas Muhammadiyah Jakarta. Jurkessia, Vol. VIII(No. 3, Juli).

Fithri, N. K. (2016). Hygiene dan Sanitasi pada Penjamah Makanan di Kantin Universitas Esa Unggul. Jurnal INOHIM, 4(2), 43-47.

Jiastuti, T. (2018). Higiene sanitasi pengelolaan makanan dan keberadaan bakteri pada makanan jadi di RSUD dr.Harjono Ponorogo. Departemen Kesehatan Lingkungan Fakultas Kesehatan Masyarakat Universitas Airlangga, 13-24.

Khaerunisa, M., Cahyono, A., \& Binawan, U. (2019). Hubungan Kebersihan Pribadi Pekerja Kantin. 1(April), 1-7.

Khairina, A.D., Palupi, I.R., \& Prawiningdyah, Y. (2019). Pengaruh Media Visual Higiene Sanitasi Makanan Terhadap Praktik Higiene Penjamah Makanan Di Kantin Kampus. Journal of Health Education, 3(2), 65-74.

Mukhodim, S., Hanum, F., \& Latifah, F. N. (2019). Pkm Kantin Sehat SMP Di Kecamatan Porong Kabupaten Sidoarjo Jawa Timur. 2(2), 159-168.

Purwanti, S., T, A. A. T., \& A, S. N. Y. R. S. (2015). Perilaku Mencuci Tangan Terhadap Angka Koloni Kuman Pada Penjamah Makanan Di Kantin Universitas Tanjungpura. Jurnal Vokasi Kesehatan, 1(2), 64-69. https://doi.org/https://doi.org/10.30602/jvk.v1i2.16

Ramli, R. (2018). Analisis Pengetahuan Penjamah Makanan Terkait Higiene Sanitasi Makanan Di "Warung Pojok" Umi. Journal of Islamic Nursing, 3(1), 20-25. https://doi.org/10.24252/JOIN.V3I1.5472 
Rismawati, R. (2018). Faktor-Faktor yang Berhubungan dengan Kelaikan Kantin Sehat di Sekolah Dasar Kecamatan Medan Belawan. Jurnal Ilmu Kesehatan Masyarakat, 7(3), 131-140. https://doi.org/10.33221/jikm.v7i3.121

Rohmah, J., Cholifah, S., \& Rezania, V. (2019). Pelatihan Higiene dan Sanitasi Makanan pada Pedagang Makanan di Kantin Sekolah Dasar. JPM (Jurnal Pemberdayaan Masyarakat), 4(1), 348-354. https://doi.org/10.21067/jpm.v4i1.3241

Sucipto, S., Rahman, F. S., \& Mustaniroh, S. A. (2018). Analisis Penilaian Konsumen terhadap Kinerja Kantin Perguruan Tinggi Analysis of Consumer' s Assessment to University Canteen Performance. Teknologi Dan Manajemen Agroindustri, $7(2), 95-106$.

Sunarya, R. O., \& Yudhastuti, R. (2019). Gambaran Higiene Dan Sanitasi Makanan Di Kantin Kampus C Universitas Airlangga Surabaya. Jurnal Kesehatan Lingkungan, 11(2 April 2019), 158-164.

Swamilaksita, P. D., \& Pakpahan, S. R. (2016). Faktor - Faktor Yang Mempengaruhi Penerapan Higiene Sanitasi di Kantin Universitas Esa Unggul Tahun 2016. Jurnal Nutrire Diaita, 8(2), 71-79.

Yulia. (2016). Higiene Sanitasi Makanan, Minuman dan Sarana Sanitasi terhadap Angka Kuman Peralatan Makan dan Minum pada Kantin. Jurnal Vokasi Kesehatan, 2(1), 55-61. 